\title{
Correlation of Base-Line Trough Tacrolimus Level With Early Rejection
}

\author{
Manish Tripathi* \\ Live donor renal transplantion, Ajman, United Arab Emirates \\ *Corresponding author: Manish Tripathi, Live donor renal transplantion, Ajman, United Arab Emirates \\ Submission: October 26, 2017; Published: January 17, 2018
}

Aim and Objective of the study

To analyze the co-relation of baseline trough ( $\mathrm{C} 0$ ) tacrolimus level, with early rejection in living donor transplants.

\section{Materials and Methods}

\section{Study area}

The study was done at Muljibhai Patel Urological Hospital, Nadiad, Gujarat. It is a tertiary health care centre, for nephrology, with a well established hemodialysis unit. We have done about 1950 renal transplantation so far. Acute rejection is the most significant risk factor for chronic rejection and potential surrogate for longterm graft failure. Aim of our study was to analyze the association between the baseline through ( $\mathrm{C} 0$ ) tacrolimus level in the first day post transplant, with early rejection in living donor transplants [110].

\section{Study population}

All patients enrolled were older than 18 years. The protocol received approval from the Ethical Committee of Muljibhai Patel Urological Hospital Society. All the patients in the study received pre-transplant immunosupression starting 3 days prior to transplant. The follow up period was 1 year post- transplant [1120].

\section{Sample size and sample technique}

179 patients were evaluated. This was an open label randomized prospective study consisting of renal allograft recipients from living donors. This study was carried out by Department of Nephrology at Muljibhai Patel Urological Hospital, Nadiad, between January 2008 to September 2009 [21-30].

\section{Data collection technique and tools}

Demographic, baseline characteristics and outcome characteristics were collected throughout the first year posttransplant. Demographic data included donor and recipient age, gender, relation and underlying native kidney disease. Baseline transplant information included induction used, anti-proliferative used, number of HLA mismatches, graft renal artery number(single or dual), WIT and CIT. Data on complications was also collected including post transplant rejections, surgical complications, infections, liver dysfunctions, PTDM, TAC nephrotoxicity, and delayed graft functions (DGF). DGF was defined as need for dialysis in the first week post-transplant. PTDM was defined as requirement for oral hypoglycemic agents or insulin for the first time post-transplant. The outcome was assessed on the incidence and severity of acute rejection in correlation to base-line trough tacrolimus level measured on day 0 of transplantation. The sideeffects of the immunosuppressive therapy was also assessed in the form of; episodes of post-transplant infection and their severity; liver dysfunction; PTDM and its severity (transient or persistent; requiring OHAs or insulin) [31-40].

Patients were divided and analyzed in three groups based on base-line trough TAC level on day 0 post-transplant: Group 1: TAC $0-5 \mathrm{ng} / \mathrm{ml}(\mathrm{n}=34)$, Group 2 : TAC 5-15ng/ml (n=112), Group 3: $\mathrm{TAC}>15 \mathrm{ng} / \mathrm{ml}(\mathrm{n}=33)$.

\section{Data Analysis}

Simple statistical tools were used for calculating demographic parameters. The difference between the two group means was tested using Student's t-test and the presence of episode within two groups by $2 \times 2$ Chi-square test. SPSS version 15.0 was used to carry the logistic regression analysis and to find the Pearson's correlation coefficients [41-50].

\section{Salient Findings (Table 1-6)}

Table 1: Comparison of the baseline demographic features between the 3 groups.

\begin{tabular}{|c|c|c|c|}
\hline & $<\mathbf{5}(\mathbf{n = 3 4 )}$ & $\mathbf{0 5}-\mathbf{1 5} \mathbf{( n = 1 1 2 )}$ & $>\mathbf{1 5}(\mathbf{n = 3 3 )}$ \\
\hline Age & $49.06+10.15$ & $47.38+9.6$ & $46.42+10.2$ \\
\hline Gender (M:F) & $24: 10$ & $94: 18$ & $27: 6$ \\
\hline Relation Related & 28 & 76 & 22 \\
\hline Other than related & 06 & 36 & 11 \\
\hline Donor Age & $49.05+10.15$ & $47.7+10.14$ & $46.42+10.2$ \\
\hline Donor Gender & $9: 25$ & $39: 73$ & $13: 20$ \\
\hline $\begin{array}{c}\text { Total Ischemia } \\
\text { Time }\end{array}$ & $61.32+17.58$ & $57.15+9.7$ & $58.42+13.61$ \\
\hline
\end{tabular}


Table 2: Various degree of HLA mismatch in all 3 groups.

\begin{tabular}{|c|c|c|c|}
\hline & $<\mathbf{5}(\mathbf{n}=\mathbf{3 4})$ & $\mathbf{0 5 - 1 5}(\mathbf{n = 1 1 2})$ & $>\mathbf{1 5}(\mathbf{n}=\mathbf{3 3})$ \\
\hline 1 & 06 & 17 & 03 \\
\hline 2 & 15 & 38 & 14 \\
\hline 3 (haplo) & 09 & 27 & 08 \\
\hline 4 & 02 & 07 & 01 \\
\hline 5 & 01 & 03 & 01 \\
\hline 6 (nil) & 00 & 05 & 01 \\
\hline
\end{tabular}

Table 3: Immunosupression protocols used and their related toxicity in the 3 groups.

\begin{tabular}{|c|c|c|c|}
\hline & $<\mathbf{5}(\mathbf{n = 3 4 )}$ & $\mathbf{0 5 - 1 5} \mathbf{( n = 1 1 2 )}$ & $>\mathbf{1 5} \mathbf{( n = 3 3 )}$ \\
\hline Induction & 15 & 35 & 17 \\
\hline $\begin{array}{c}\text { Anti proliferative } \\
\text {-Azathioprine }\end{array}$ & 20 & 50 & 11 \\
\hline $\begin{array}{c}\text { Anti proliferative - } \\
\text { MMF }\end{array}$ & 14 & 62 & 22 \\
\hline $\begin{array}{c}\text { Biopsy proven CNI } \\
\text { toxicity }\end{array}$ & $2(5.9)$ & $9(8.03)$ & $5(15.1)$ \\
\hline NOD & $17(50)$ & $42(37.5)$ & $14(42.4)$ \\
\hline
\end{tabular}

Table 4: Non-infectious complications occurring during hospitalization and outpatient follow-up.

\begin{tabular}{|c|c|c|c|c|}
\hline $\begin{array}{c}\text { Non-Infectious } \\
\text { Complications }\end{array}$ & $\mathbf{< 0 5}$ & $\mathbf{0 5 - 1 5}$ & $\mathbf{> 1 5}$ & $\begin{array}{c}\text { Total case } \\
(\mathbf{n = 1 0})\end{array}$ \\
\hline Femoral neuropathy & 01 & - & 01 & 02 \\
\hline GI side effects of MMF & - & - & 03 & 03 \\
\hline $\begin{array}{c}\text { Hypertensive } \\
\text { encephalopathy }\end{array}$ & - & 01 & - & 01 \\
\hline Proteinuria & - & - & 01 & 01 \\
\hline TMA & - & 01 & - & 01 \\
\hline TRAS & - & 02 & - & 02 \\
\hline
\end{tabular}

Table 5: Infectious complications.

\begin{tabular}{|c|c|c|c|c|}
\hline $\begin{array}{c}\text { Post } \\
\text { transplant } \\
\text { Infections }\end{array}$ & $<\mathbf{0 5}$ & $\mathbf{0 5 - 1 5}$ & $>\mathbf{1 5}$ & $\begin{array}{c}\text { Total case } \\
\text { (n=57) }\end{array}$ \\
\hline AGE & 01 & 04 & - & 5 \\
\hline CMV & 02 & 08 & 04 & 14 \\
\hline FUNGAL & 01 & - & - & 1 \\
\hline LRTI & 01 & 01 & 01 & 3 \\
\hline TB & 01 & 01 & - & 2 \\
\hline UTI & 05 & 11 & 07 & 26 \\
\hline HBV & - & 02 & 01 & 3 \\
\hline HCV & - & - & 01 & 1 \\
\hline Lymphocoel & - & 01 & - & 1 \\
\hline VZ-1 & - & 01 & - & 1 \\
\hline PV-1 & - & 01 & - & 1 \\
\hline
\end{tabular}

Table 6: Number of rejection in each group, their Banff grading and outcomes.

\begin{tabular}{|c|c|c|c|}
\hline & $<5(\mathrm{n}=34)$ & $05-15(\mathrm{n}=112)$ & $>15(\mathrm{n}=33)$ \\
\hline $\begin{array}{c}\text { Rejection } \\
\text { Episodes }\end{array}$ & $12(35.3)$ & $27(24.1)$ & $5(15.2)$ \\
\hline TCMR 1A & 3 & 10 & 2 \\
\hline TCMR 1B & 3 & 3 & 0 \\
\hline TCMR 2A & 2 & 4 & 0 \\
\hline AMR 1 & 1 & 3 & 0 \\
\hline AMR 3 & 0 & 1 & 0 \\
\hline Graft loss & 0 & 2 & 0 \\
\hline $\begin{array}{c}\text { Post Tx } \\
\text { Infections }\end{array}$ & $12(35.3)$ & $33(29.5)$ & $15(45.4)$ \\
\hline
\end{tabular}

Our study showed a significant reduction in the incidence of early rejection as the baseline (pre-transplant) trough tacrolimus level increases. Patients in Group 3 had significantly lower rate of biopsy proven rejections than Group $1(\mathrm{p}=0.001)$. It also shows that with higher trough level severity of rejection also reduces and that there was no severe TIR and antibody mediated rejection when trough level was $>15 \mathrm{ng} / \mathrm{ml}$ [51-60].

Our study also showed that the incidence of NODAT was not different among various trough levels; although there was a trend towards higher rate of biopsy proven nephrotoxicity with higher trough levels. It was also seen that only $18 \%$ of the patients could achieve a baseline trough level of $>15 \mathrm{ng} / \mathrm{ml}$ inspite of being started on same doses of tacrolimus $(0.15 \mathrm{mg} / \mathrm{kg})$ pretransplant. This shows a wide variability in tacrolimus handling in humans [61-75].

\section{Conclusion}

i. Incidences of early rejection reduces as the pretransplant trough tacrolimus level increases [71]

ii. With higher trough level severity of rejection also reduces and we did not encounter any severe TIR or antibody mediated rejection when trough level was $>15 \mathrm{ng} / \mathrm{ml}$ [72]

iii. NOD was not different among various trough levels and trend towards higher nephrotoxicity with higher trough levels [73]

iv. Only $18 \%$ could achieve the trough level of $>15 \mathrm{ng} / \mathrm{ml}$ $[74,75]$

\section{Recommendation}

Our results suggest that targeting baseline (pretransplant) trough (T0) tacrolimus levels similar to those seen in Group 3 ( $>15 \mathrm{ng} / \mathrm{ml}$ ) immediately post-transplant can yield extremely low ACR rates in the long term. Thus, we propose that a target baseline trough tacrolimus levels similar to that seen in Group 3 would achieve the optimal balance between efficacy and toxicity.

\section{References}

1. Arrazola L, Sozen H, Humar A, Papalois V, Uknis M,et al. (2000) Both immunologic and nonimmunologic factors are risks for long-term graft survival - a multivariate analysis. Transplant Proc 32(7): 1831. 
2. Humar A, Ramcharan T, Kandaswamy R, Gillingham K, Payne WD, et al. (2002) Risk factors for slow graft function after kidney transplants: a multivariate analysis. Clin Transplant 16(6): 425-429.

3. Paraskevas S, Kandaswamy R, Humar A, Gillingham K, Gruessner RW, et al. (2003) Predicting long-term kidney graft survival: can new trials be performed? Transplantation 75(8): 1256-1259.

4. Suthanthiran M, Strom TB (1994) Renal transplantation.N Engl J Med 331(6): 365-376

5. Magee CC, Denton MD, Mieford EL. (1999) Immunosuppressive agents in organ transplantation. Hosp Med 1999:60: 364.

6. http://www.centerspan.org.

7. Lindholm A, Ohlman S, Albrechtsen D, Tufvenson G, Persson H, et al. (1993) The impact of acute rejection episodes on long term graft functionand outcome in 1337 primary renal transplants treated by 3 cyclosporin regimens. Transplantation 56: 307-315.

8. Matas AJ, Gillingham KJ, Payne WD, Najarian JS (1994) The impact of an acute rejection episode on long-term renal allograft survival. Transplantation 57(6): 857-859.

9. Takahara S, Kokado y, Kameoka H, Takano Y, Moutabarrik et al. (1994) A Monitoring of FK506 blood levels in kidney transplant recepients. Transplantation Porc 26(4): 2106-2108.

10.Kerhner R, Fitsimmons WE (1996) Relatioship of FK 506 whole blood concentrations and efficacy and toxicity after liver and kidney transplantation. Transplantation 62(7): 920-926.

11.Winker M, Wonigeit K, Undre N (1995) Comparison of plasma vs whole blood as matrix for FK506 drug level monitoring. Transplantation Proc 27: 822-825.

12.Undre NA, van Hooff J, Christianns M, Vanrenterghem Y, Donck J, et al. (1999) Low systemic exposure to Tacrolimus correlates with acute rejection. Transplant Proc 31(1-2): 296-298.

13. Backman L, Levy MF (1995) Klintmalm and the FK506 Multicentre Study Group. Whole-blood and the plasma levels of FK506 after liver transplantation: Results from the US Multicenter Trial. Transplant Proc 27: 1124

14.Backman L, Nicar M, Levy M, Distant D, Eisenstein C, et al. (1994) FK506 trough levels in whole blood and plasma in the liver transplant recepients. Transplantation 57(4): 519-525

15.Jain AB, Todo S, Fung JJ, R Venkataramanan, R Day, et al. (1991) Correlation of rejection episodes with FK 506 level and the steroids following primary orthotropic liver transplantation. Transplant Proc 23(6): 3023-3025

16.Japanese FK506 Study Group (1991) Japanese study of FK506 on kidney transplantation: The benefit of monitoring the whole blood FK506 concentration. Tansplant Proc 23: 3023-3025.

17. Bottiger Y, Battstrom C, Tyden G, Sawe J, Groth CG (1999) Tacrolimus whole blood concentrations correlate closely to side-effects in renal transplant recepients. Br J Clinical Pharmacology 48(3): 445-448.

18.Winkler M, Ringe B, Baumann J, Loss M, Wonigiet K, et al. (1994) Plasma vs whole blood for therapeutic drug monitoring of patients receving FK 506 for immunosuppression. Clin Chem 40(12): 2247-2253

19.Winkler M, Wonigeit K, Undre N, Ringe B, et al. (1995) Comparision of plasma vs whole blood as matrix for FK 506 drug level monitoring. Transplant Proc 27(1): 822-825.

20. Mayer AD, Dmitrewski J, Squifflet JP, Besse T, Grabensee B et al. (1997) Multicenter randomized trial comparing tacrolimus (FK506) and cyclosporine in the prevention of renal allograft rejection: a report of the European Tacrolimus Multicenter Renal Study Group. Transplantation 64(3): 436-443

21.Pirsch JD, Miller J, Deierhoi MH, Vincenti F, Filo RS et al. (1997) A comparison of tacrolimus (FK506) and cyclosporine for immunosuppression after cadaveric renal transplantation. FK506 Kidney Transplant Study Group. Transplantation 63(7): 977-983.

22. Jensik SC (1998) Factors affecting the pharmacokinetics of tacrolimus in the first year after renal transplantation. European Tacrolimus Multicentre Renal Study Group. Transplant Proc 30(4): 1261-1263.

23. Mayer AD (1999) Four year follow up of European tacrolimus multi center renal study. Tr Transplant Proc 31(7A): 27S-28SC

24. Johnson, Ahsan N, Gonwa T, Halloran P, Stegall M, et al. (2000) Randomized trial of tacrolimus in combination with azathiprine or mycophenolate mofetil versus cyclosporine with mycophenolate mofetil after cadaveric renal transplant. Transplantation 69(5): 834-841.

25. Schweitzer EJ, Matas AJ, Gillingham KJ, et al. (1991) Causes of renal allograft loss: progress in the 1980s, challenges for the 1990s. Ann Surg 214(6): 679-688.

26. Massy ZA, Guijarron C, Wiederkehr MR, Ma JZ, Kasiske BL (1996) Chronic renal allograft rejection: Immunologic and nonimmunologic risk factors. Kidney Int 49(2): 518-524.

27. Matas ZA, Guijarro C, Wiederkehr MR, Ma JZ, Kasiske BL (1996) Chronic renal allograft rejection: Immunological and nonimmunological risk factors. Kidney Int 49(2): 518-524.

28. Matas AJ, Gillingham KJ, Payne WD, Najarian JS (1994) The impact of acute rejection episode on long-term renal allograft survival( $\mathrm{t} 1 / 2)$. Transplantation 57(6): 857-859.

29. Cosio FG, Pelletier RP, Falkenhain ME, Henry ML, Elkhammas EA, et al. (1997) Impact of acute rejection and early allograft function on renal allograft survival. Transplantation 63(11): 1611-1615.

30. Opelz G (1997) for the Collaborative transplant study. Critical evaluation of the association of acute with chronic graft rejection in kidney and heart transplant recepients. Transplant Proc 29(1-2): 73-76.

31. O’Keefe SJ, Tamura J, Kincaid RL, Tocci MJ, O’Neill EA (1992) FK-506-and CsA- sensitive activation of the interleukin-2 promoter by calcineurin. Nature 357(6380): 692-694.

32. Clipstone NA, Crabtree GR (1992) Idnetification of calcineurin as a key signaling enzyme in T-lymphocyte activation. Nature 357: 695-697.

33. Liu J, Farmer JD, Lane WS, Friedman J, Weissman I, et al. (1991) Calcineurin is a common target of cyclophilin-cyclosporin A AND fkbpfk506 complexes.Cell 66(4): 807-815.

34. Fruman DA, Klee CB, Biere BE, Burakoff SJ (1992) Calcineurin phosphatease activity in T lymphocytes is inhibited by FK 506 and cyclosporine A. Proc Natl Acad Sci U S A 89(9): 3686-3690.

35. Schreiber SL (1992) Immunophilin-sensitive protein phosphatase action in cell sinaling pathways. Cell 70(3): 365-368.

36. Cecka JM, Terasaki PI (1995) The UNOS Scientific Renal Transplant Registry. In: Terasaki PI, Cecka JM,eds, Clinical transplants 1992. Los Angeles UCLA Tissue Typing Laboratory 1-18.

37. Terasaki PI, Cecka JM, Gjertson DW, Cho Y, Takemoto S, Cohn M (1993) A ten-year prediction for renal transplant survival. In; Tersaki PI, Cecka JM, eds. Clinical transplants 1992. Los Angeles: UCLA Tissue Typing Laboratory pp. 501-512.

38. Basdonna GP, Matas AJ, Gillingham KJ, Payne WD, Dunn DL, et al. (1993) Relationship between early and late acute rejection and onset of chronic rejection in kidney transplantation. Transplant Proc 25(1-2): 910-911.

39. Almond PS, Matas A, Gillingham K, Dunn DL, Payne WD, et al. (1993) Risk factors for chronic rejection in renal allograft recepients. Transplantation 55(4): 752-756.

40. Basdonna GP, Matas AJ, Gillingham KJ, Payne WD, Dunn DL, et al. (1993) Early versus late acute renal allograft rejection: impact on chronic rejection. Transplantation 55(5): 993-995.

41. Land W, Schneeberger H, Schleibner S (1991) Long-term results in cadaveric renal transplantation under cyclosporine therapy. Transplant 
Proc 23: 1244.

42. Matas A (1994) Chronic rejection in renal transplant recepients: risk factor and correlates. Clin Transplant 8(3-2): 332-335.

43. Vanrenterghem YF (1995) Acute rejection and renal allograft outcome. Nephrol Dial Transplant 10(suppl 1): 29-31.

44. Lindholm A, Ohlman S, Albrechtsen D, Tufveson G, Persson H, et al. (1993) The impact of acute rejection episodes on longh term graft function and outcome in 1347 primary renal transplants treated by 3 cyclosporin regimens. Transplantation 56(2): 307-315.

45. Cecka JM, Terasaki PI (1991) The UNOS scientific renal transplant registry, 1990. In: Treasaki P (Eds.), Clinical transplants 1990. Los Angeles: UCLA Tissue typing laboratory 1991: 1-18.

46. Cecka JM, Terasaki PI. (1995) The UNOS scientific renal transplant registry. In: Terasaki PI, Cerka JM (Eds.), Clinical transplants 1994. Los Angeles: UCLA Tissue Typing Laboratory, p. 1-18.

47. Japanese FK 506 Study Group (1991) Japanese study of FK 506 on kidney transplantation: results of an early phase 2 study. Transplant Proc 23(6): 3071-3074.

48. Japanese FK (1993) 506 Study Group. Japanese study of FK 506 on kidney transplantation: results of an early phase 2 study. Transplant Proc 25: 649 .

49. Japanese FK (1995) 506 Study Group. FK 506: Long term study in kidney transplantation. Transplant Proc 27: 818.

50. Japanese FK 506 (1995) Study Group. Phase 3 study of FK 506 in kidney transplantation. Transplant Proc 27: 829.

51. Schleibner S,Krauss M, Wagner K, Erhard J, Christiaans M, et al. (1995) FK 506 versus cyclosporine in the prevention of renal allograft rejection: European pilot study-six-week results. Transpl Int 8(2): 86-90.

52. Laskow DA, Vincenti F, Neylan J, Mendez R, Matas A (1995) Phase 2 FK 506 multicenter concentration control study: one-year follow up Transplant Proc 27(1): 809-811.

53. Shapiro R, Jordan M, Scantlebury V, Fung J, Jensen C, et al. (1991) FK 506 in the clinical kidney transplantation. Transplant Proc 23(6): 30653067.

54. Shapiro R, Jordan M, Scantlebury V, et al. (1995) A prospective randomized trial of FK 506- based Immunosuppression after renal transplantation. Transplantation 344: 423.

55. Jordan ML, Shapiro R, Vivas CA, Velma P. Scantlebury, Parmjeet Rhandhawa, et al. (1994) FK506 "rescue" for resistant rejections of renal allografts under primary cyclosporine Immunosuppression. Transplantation 57(6): 860-865.

56. Undre NA, Stevenson P, Schafer A (1999) Pharmacokinetics of tacrolimus: clinically relevant aspects. Transplant Proc 31(7): 21-24.

57. Undre NA, van Hooff J, Christiaans M, Vanrenterghem Y, Donck J, (1999) et al. Low systemic exposure to tacrolimus correlates with acute rejection. Transplant Proc 31(1-2): 296-298.

58. Bottiger Y, Undre NA, Sawe J, Stevenson PJ, Ericzon BG (2002) Effect of bile flow on the absorption of tacrolimus in the liver allograft transplantation. Transplant Proc 34(5): 1544-1545.

59. Kershner RP, Fitzsimmons WE (1996) Relationship of FK506 whole blood concentrations and efficacy and toxicity after liver and kidney transplantation. Transplantation 62(7): 920-926.

60. Pirsch JD, Miller J, Deierhoi MH, Vincenti F, Filo RS (1997) A comparison of tacrolimus (FK506) and cyclosporine for immunosuppression after cadaveric renal transplantation. FK506 Kidney Transplant Study Group. Transplantation 63(7): 977-983.

61. Mayer AD, Dmitrewski J, Squifflet JP, Besse T, Grabensee B, et al. (1997) Multicenter randomized trial comparing tacrolimus (FK506) and cyclosporine in the prevention of renal allograft rejection: A report of the European Tacrolimus Multicenter Renal Study Group. Transplantation 64(3): 436-443.

62.Morris-Stiff G, Ostrowski K, Balaji V, Moore R, Darby C, et al. (1998) Prospective randomised study comparing tacrolimus (Prograf) and cyclosporin (Neoral) as primary immunosuppression in cadaveric renal transplants at a single institution: Interim report of the first 80 cases. Transpl Int 11(Suppl 1): S334-S336.

63. Busque S, Shoker A, Landsberg D, McAlister V, Halloran P, et al. (2001) Canadian multicentre trial of tacrolimus/azathioprine/steroids versus tacrolimus/mycophenolate mofetil/steroids versus neoral/ mycophenolate mofetil/steroids in renal transplantation. Transplant Proc 33(1-2): 1266-1267

64. Margreiter R (2002) Efficacy and safety of tacrolimus compared with ciclosporin microemulsion in renal transplantation: A randomized multicentre study. Lancet 359(9308): 741-746.

65. Murphy GJ, Waller JR, Sandford RS, Furness PN, Nicholson ML (2003) Randomized clinical trial of the effect of micro microemulsion cyclosporin and tacrolimus on renal allograft fibrosis. Br J Surg 90(6): 680-686.

66. Charpentier B, Rostaing L, Berthoux F, Lang P, Civati G (2003) A threearm study comparing immediate tacrolimus therapy with antithymocyte globulin induction therapy followed by tacrolimus or cyclosporine $\mathrm{A}$ in adult renal transplant recipients. Transplantation 75(6): 844-851.

67.Hardinger KL, Bohl DL, Schnitzler MA, Lockwood M, Storch GA, et al. (2005) A randomized, prospective, pharmacoeconomic trial of tacrolimus versus cyclosporine in combination with Thymoglobulin in renal transplant recipients. Transplantation 80(1): 41-46.

68. Rostaing L, Cantarovich D, Mourad G, Budde K, Rigotti P (2005) Corticosteroid-freeimmunosuppression with tacrolimus, mycophenolate mofetil, and daclizumab induction in renal transplantation. Transplantation 79(7): 807-814.

69. Ekberg H, Tededsco-Silva H, Demirbas A, Vitko S, Nashan B (2006) Symphony: Comparing standard immunosuppression to low-dose cyclosporine, tacrolimus or sirolimus in combination with MMF daclizumab and corticosteroids in renal ransplantation. Transplantation 82: 83.

70.Dunn CJ, Wagstaff AJ, Perry CM, Plosker GL, Goa KL (2001) Cyclosporin: An updated review of the pharmacokinetic properties, clinical efficacy and tolerability of a microemulsion-based formulation (Neoral)1 in organ transplantation. Drugs 61(13): 1957-2016.

71.Christiaans M, van Duijnhoven E, Beysens T, Undre N, Schafer A, et al. (1998) Effect of breakfast on the oral bioavailability of tacrolimus and changes in harmacokinetics at different times posttransplant in renal transplant recipients. Transplant Proc 30(4): 1271-1273.

72. Halloran PF, Helms LM, Kung L, Noujaim J (1999) The temporal profile of calcineurin inhibition by cyclosporine in vivo. Transplantation 68(9): 1356-1361.

73. Stein CM, Murray JJ, Wood AJ (1999) Inhibition of stimulated interleukin-2 production in whole blood: A practical measure of cyclosporine effect. Clin Chem 45(9): 1477-1484.

74. Hartel C, Fricke L, Schumacher N, Kirchner H, Muller-Steinhardt M (2002) Delayed cytokine mRNA expression kinetics after T-lymphocyte costimulation: A quantitative measure of the efficacy of cyclosporin A-based immunosuppression. Clin Chem 48(12): 2225-2231.

75.Sommerer C, Konstandin M, Dengler T, Schmidt J, Meuer S, et al. (2006) Pharmacodynamic monitoring of cyclosporine a in renal allograft recipients shows a quantitative relationship between immunosuppression and the occurrence of recurrent infections and malignancies. Transplantation 82(10): 1280-1285. 